\title{
FÜTÉS OPTIMALIZÁLÓ ÉS FELÜGYELETI RENDSZER FEJLESZTÉSE
}

\author{
Hegyi Ádám \\ tanszéki mérnök, Miskolci Egyetem, Automatizálási és Infokommunikációs Intézet \\ Cím: 3515 Miskolc, Miskolc-Egyetemváros, e-mail: qgehadam@uni-miskolc.hu
}

\begin{abstract}
Absztrakt:
Manapság az okos otthonok elterjedésével megnött az igény az olyan rendszerekre, amelyek olcsó megoldást biztositanak a házunk automatizálására. Egy olyan eszközre van szükség, amely képes megteremteni az egyensúlyt a komfortérzet és az energiafogyasztás között, úgy, hogy az egy átlagos háztartás is megengedheti magának és a beszerelése, müködtetése sem igényel szakembert. Az általunk tervezett eszköz használata egyszerü és független a ház szabályozó rendszereitöl, igy bármilyen háztartásba implementálható. Az elmúlt év során nagy utat jártunk be az eszköz fejlesztése során, számos tapasztalatot gyüjtöttünk a szenzorok müködtetésében, a hálózatok felépitésében, valamint a komfortparaméterek élettani hatásaiban. A továbbiakban ezeket a tapasztalatokat szeretnénk beépiteni a kész tanácsadó rendszerbe, hogy elérjük a kitüzött célt.
\end{abstract}

Kulcsszavak: okos otthon, automatizálás, IoT, energiahatékonyság, adatgyüjtés

\begin{abstract}
:
Nowadays, with the spread of smart homes, there is a growing need for systems that provide a low-cost solution for automating our homes. There is a need for a device that can balance comfort and energy consumption so that an average household can afford it, and its installation and operation do not require any specialist. The device we design is simple to use and independent of the house's control systems, so it can be implemented in any household. Over the past year, we have come a long way in developing the device, gaining a lot of experience in sensor operation, network construction, and the physiological effects of comfort parameters. In the future, we would like to use this experience into our finished advice based system in order to achieve our goal.
\end{abstract}

Keywords: smart home, automation, IoT, energy efficiency, data collection

\section{Bevezetés}

Egy eszköz, amely képes megtanulni a felhasználó igényeit, sokat segíthet az okos otthonok fejlődésében és egyensúlyt teremt a komfort és energia fogyasztás között. Az okos otthonok azonban egyelöre nagyon költséges befektetésnek számítanak, így nem engedheti meg magának mindenki, viszont a nem megújuló energiaforrások pazarló használata globális probléma és az okos otthonok önmagukban nem jelentenek megoldást, mivel nincsenek elég széles körben elterjedve. Minél többen használnak energia fogyasztást csökkentő megoldásokat, annál nagyobb behatása lesz az összfogyasztásra, ehhez viszont olyan low-cost megoldások kellenek, amelyek segítségével többen hozzájuthatnak ilyen és ehhez hasonló szabályozó rendszerekhez. Müködése során számos paramétert figyelembe vesz, ilyenek a hőmérséklet, a páratartalom, a szén-dioxid és az illékony szerves vegyületek szintjét, a fényerősséget és a nyílászárók állapota. A paramétereket kiértékelve utasítást küld a felhasználónak, miként optimalizálhatja a komfort szintjét az energiafogyasztás függvényében. A 
rendszert először a Magyarországon megrendezett Solar Decathlon Europe 2019 versenyen teszteltük éles üzemben, ahol a tanácsadáson kívül egyéb teendőket is ellát, még most is a ház önálló okos otthon rendszerébe implementálva szolgáltatja az adatokat a ház gépészeti berendezéseinek, így segítve a hütésfütés szabályozását. [6] A tanácsadó rendszer egyelőre előre beállított értékekkel müködik, vagyis mi adtuk meg mik legyenek az ideális komfortérzet határértékei. Ha a valamely paraméter ezt a határértéket átlépi és a gépészet nem tud vagy nem tud gazdaságosan változtatni ezen, egy e-mailt kapunk, amely megmondja mi a teendőnk, hogy optimális legyen a komfortérzet. Képes továbbá az adatok mentésére is, ezeket felhasználva összefüggéseket vonhatunk le és egy tanuló algoritmust integrálva képes lesz a lakó igényeihez igazodni, komfortos légteret és optimálisabb fogyasztást biztosítani, mindezt egyszerü parancsok által. A végső cél egy olyan adatgyüjtő és tanácsadó eszköz, amely adaptív algoritmusának segítségével a kényelem feláldozása nélkül csökkenthetjük a költségeinket és mivel az eszköz elsődleges célja a megfizethetőség, egyre többen használhatnak ilyen rendszereket, amely globálisan is hozzájárul az energiaforrásaink kihasználásának optimalizálásához.

\section{Komfortelmélet}

A komfortelmélet a zárt terekben foglalkozik az emberek közérzetével, a feladat megértéséhez fontos volt megismerni a komfortos légkör paramétereit. A közérzet a komfort érzetböl, a hőérzetből, vizuális és akusztikai komfortból, valamint a zárt belső terek levegő minőségéből adódik. A zárt terek vonatkozásában a szubjektív közérzet fogalmát alkalmazzák, miszerint a közérzet a komplex hatások alapján az egyénekben kialakuló szubjektív érzés, általában ez a definíció elterjedt. Zárt térben tartózkodó ember esetében azonban alkalmaznak egy másik szubjektív definíciót is és ez a komfortérzet. $\mathrm{Az}$ ezt elsősorban befolyásoló tényezők a hőmérséklet, a nedvesség, a légmozgás, a zaj és a megvilágítás. A hőérzet a levegő hőmérséklete, annak térbeli és időbeli eloszlása, változása, a környező felületek közepes sugárzási hőmérséklete, a levegő relatív nedvességtartalma, a levegőben lévő vízgőz parciális nyomása, a levegő sebessége és a test hőmérséklete adja. Továbbá a ruházatunk hőszigetelő képessége és a párolgást befolyásoló hatása is részt vesz a höérzet meghatározásában. Vannak müszakilag nem megváltoztatható tényezők, ez az egyén kora, neme stb., ezek is bizonyos fokig hatással vannak rá. Mivel ez egy szubjektív érték, nehéz pontosan meghatározni, mindenkinek egyénileg más és mást jelent a „kellemes” hőmérséklet. A legelterjedtebb a következő 7 pontos skála. [1]

1. táblázat. A hömérséklet hatása a komfortérzetre

\begin{tabular}{l|l} 
Forró & 3 \\
\hline Meleg & 2 \\
\hline Kellemesen meleg & 1 \\
\hline Neutrális & 0 \\
\hline Kellemesen hüvös & -1 \\
\hline Hüvös & -2 \\
\hline Hideg & -3
\end{tabular}

Hőérzetet befolyásoló tényezők:

- a levegő hőmérséklete, annak térbeli, időbeli eloszlása, változása,

- a környező felületek közepes sugárzási hömérséklete,

- a levegő relatív nedvességtartalma, illetve a levegőben lévő vízgőz parciális nyomása,

- a levegö sebessége, 
- az emberi test hőtermelése, hőleadása, hőszabályozása,

- a ruházat hőszigetelő képessége, párolgást befolyásoló hatása.

Az első négy fizikai paraméter, míg az utóbbi kettő az emberi szervezet alkalmazkodóképességével függ össze, a hőháztartás egyensúlyának fenntartása érdekében fontos. Például az emberi test hőtermelése, amely elsősorban a végzett tevékenység függvénye, de belejátszik bizonyos fokig az egyén kora, neme stb., tehát ez müszakilag nem változtatható, az emberi test hőleadása, amely viszont nagymértékben függ a ruházkodástól, valamint az előzőekben említett müszaki paraméterek hatásától.

A komfortra nagy hatással van továbbá a páratartalom is. Az egészséges felnőtt ember számára a 4060 százalékos páratartalom az optimális, mind a komfortérzet, mind az egészségmegörzés céljából. A levegő túl magas páratartalma nem egészséges, ugyanis kedvez számos kórokozó, atka és gomba elszaporodásának. A túl párás levegő növeli az allergiák kialakulásának kockázatát, elsősorban a házipor (poratka) esetében.[1]

A nemzetközi gyakorlatban leggyakrabban alkalmazott definíció értelmében a belső levegő minőség alatt a komfort terek levegöjének minden olyan nem termikus jellemzőjét értjük, melyek az ember közérzetét befolyásolják. A belső levegő minőséget befolyásoló szennyezőanyagok:

- gázok és gözök (pl. CO, CO2, SO2, NO2, NOx, O3, Radon)

- szaganyagok (pl. szerves anyagok bomlástermékei, emberi, állati és növényi eredetủ szaganyagok, építő és burkoló anyagok kipárolgási termékei)

- aerosolok (porok, lebegő anyagok, nehézfém szálak, pollen anyagok)

- vírusok

- baktériumok és spórák (pl. legionella baktérium)

- gombák és spóráik (pl. nedvesítő kamra kórokozói) [4]

\section{A tanácsadó rendszer felépítése}

Egyetemünk egy eszköz fejlesztése zajlik, amely segítségével úgy fejleszthetjük otthonunk automatizáltságát, hogy közvetlenül nem avatkozunk be a ház szabályozó rendszerébe. A tervezett rendszer úgy segít a költségeink csökkentésében, hogy közvetlenül nem vezérel semmit, így az aktuátorok és a költséges robosztus szabályozó rendszerek árát megspórolhatjuk, valamint törekedni kell a szenzor hálózat méretének és komplexitásának csökkentésére. Ezt úgy lehet biztosítani, hogy csak a legszükségesebb paramétereket méri a rendszer és ennek segítségével határozza meg azokat a sémákat, amelyek a helytelen használatra utalnak, ezek után ajánlatokat kapunk arra, hogyan állítsuk be a fútést, vagy mikor szellőztessünk. Az ajánlatokat valamilyen interfészen, akár a telefonunkon is megkaphatjuk, így egyszerüsítve a rendszert és csökkentve a költségeket. Az eszköz célja, hogy megteremtse az egyensúlyt a komfortérzet és az energiafogyasztás között, ezáltal maximalizálva mindkettőt. Müködése egyszerü, a levegő számos paramétereit mérve és ezeket analizálva döntéseket képes hozni, melyek segítségével beállítja a komfortot az energiafogyasztást figyelembe véve. Terveink szerint az interfész egy olyan telefonos alkalmazás lesz, amellyel valós időben folyamatosan monitorozhatjuk ezeket a paramétereket, ezeket elmenthetjük és lekérdezhetjük az eszköz müködésének hatékonyságát, ezek mellett a legfontosabb része a tanácsadó rendszer. Mikor az eszköz eldönti, hogyan kell beavatkozni, nem fog tudni, hiszen nincs becsatolva semmilyen szabályozó rendszerbe, ezért tanácsot ad a felhasználónak az alkalmazáson keresztül, mint például, nyissa ki az ablakot, vagy épp vegye lejjebb a termosztát set-point-ját, mert sokat szellőztet és nem hatékony a fütés. Az adatok analizálását egy öntanuló algoritmus fogja végezni. Az algoritmus betanítását fogjuk végezni az elkövetkezendő időszakban, amely egy több hónapos mérést fog jelenteni, ahol az eszköz nem fogja ellátni a feladatát, csak adatokat gyüjt, majd ezen adatok alapján megtörténik a betanítás, a rendszer továbbá képes lesz a 
folyamatos öntanulásra is, tehát menet közben is alkalmazkodni fog, de a felhasználó is korrigálhatja a müködést az interfész segítségével. [5]

A mérés során számos paramétert fogunk megfigyelni, ezek a hőmérséklet, páratartalom, légnyomás, szén-dioxid, fényerősség, továbbá megfigyeljük az ajtók és ablakok nyitását, ezáltal lehet korrelációt keresni a szellőztetés és a paraméterek változása között. A mérés során két ilyen szenzor csomag lesz elhelyezve a házban. A szenzorcsomagok adatait egy RaspberryPi típusú mikroszámítógép fogja gyüjteni, és ezeket egy NodeRed felületen bármikor meg tudunk tekinteni (1.ábra). A ház rendelkezik egy fejlett Loxone típusú okos otthon rendszerrel, melyhez már csatoltuk az eszközt, így a hőszabályozást már ezen rendszer adatai alapján végzi a ház. Fontos megjegyezni, hogy ez még nem a végleges rendszer, így a fényerősséget és a nyílászárók állapotát nem tudja figyelni. Mivel a ház egy olyan versenyre épült, amely egyik fö irányelve a fenntarthatóság és a környezetbarát technológia, a szenzorcsomag kialakítását és müködését is így próbáltuk megvalósítani.

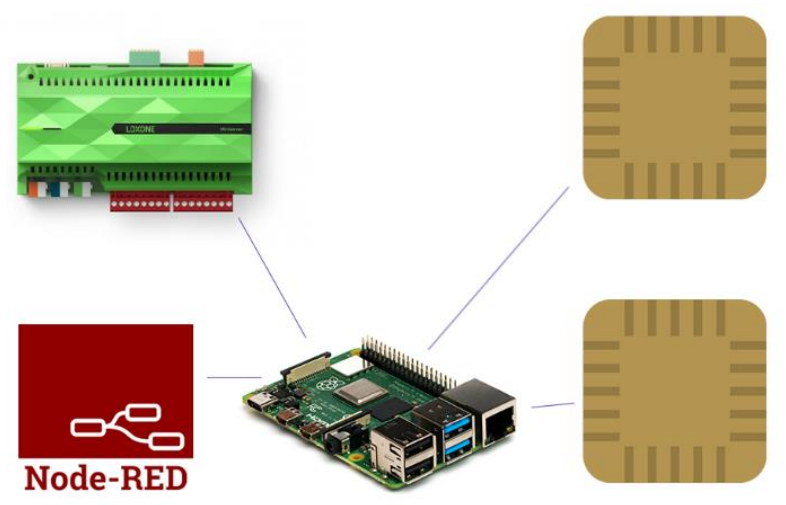

\section{1. ábra. A szenzorcsomagok hálózata a házban}

\section{Az eszköz fejlesztése}

Az első prototípus a 2018-as Tudományos Diákköri konferenciára készült, az alapvető elképzelés ekkor még az volt, hogy egy olyan eszközt fejlesszünk, amely képes felmérni egy épület energiamérlegét és mobilis módon tudja monitorozni a szabályozórendszerek energiahatékonyságát (2. ábra). [5]

Ez az eszköz két típusú szenzort használt. A BME280 egy Bosch gyártmányú hőmérséklet érzékelö, ezen kívül legnyomást és páratartalmat is képes vizsgálni, kis 2,5mm-es mérete lehetővé teszi, hogy bármilyen hordozható eszközbe, akár okos órába is beépíthető legyen. Linearitását tekintve közel lineáris, de korrigálási lehetőséggel is rendelkezik. Ezen kívül rendelkezik egy TSL2591 szenzorral, amely fényintenzitást képes mérni. A kommunikációhoz I2C (Inter-Integrated Circuit) buszt használ.

Az első fázisban számos tapasztalatot szereztünk a szenzorok használatában és müködésében, amelyek segítették a további munkát. Felépítését tekintve egyszerü, az I2C buszon keresztül két Arduino Leonardo gyüjti az adatokat, amelyeket egy RTC óramodullal vannak szinkronizálva. Az adatokat azonnal továbbítják egy számítógépnek, ami soros porton keresztül menti az adatokat. A buszon három BME280 és két TSL2591-es szenzor van, ezek segítségével a teszt időszak alatt monitorozni tudtuk a beltéri és kültéri hömérsékletet, páratartalmat, légnyomást és fényintenzitást, valamint tudni szerettük volna, mikor és hogyan üzemel a fütötest, és ez milyen hatással van a paraméterekre, így a harmadik BME280 szenzor, amelyet a radiátor közvetlen közelében helyeztünk el ezért felelt. [2][3] 


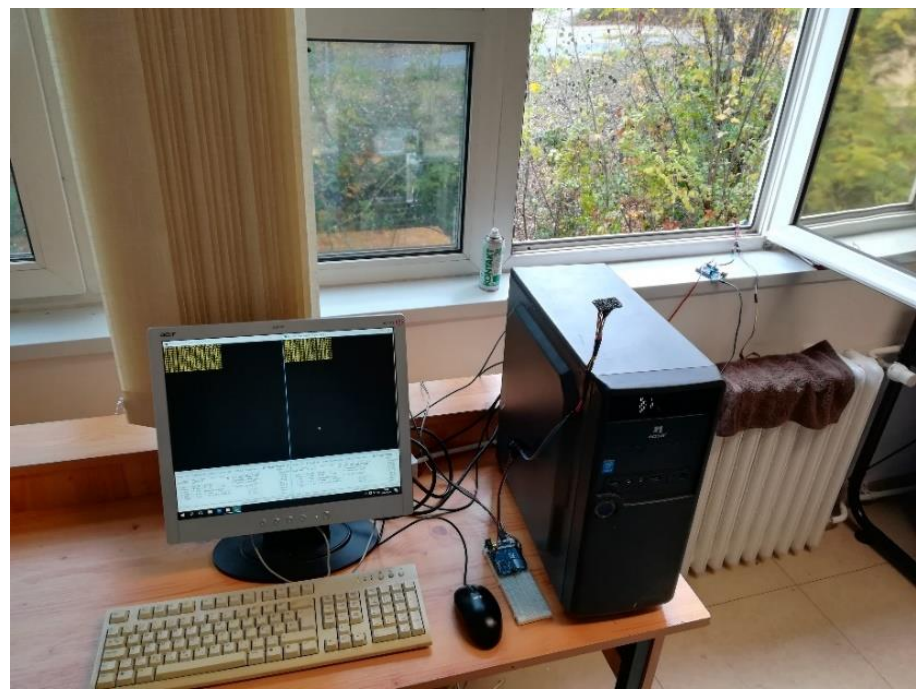

2. ábra. Az első prototípus

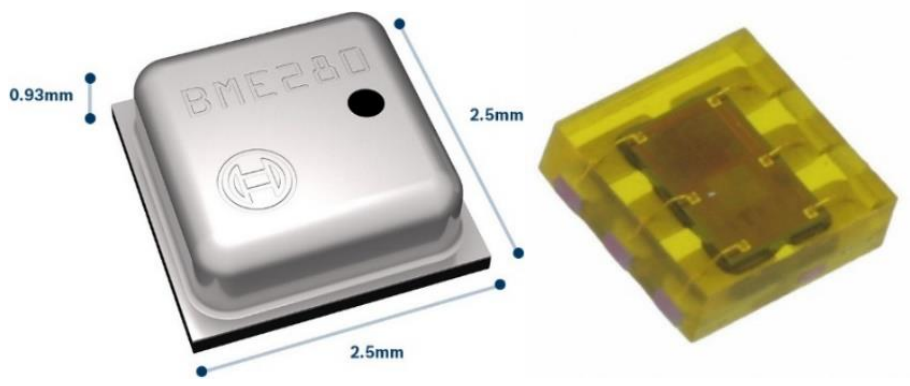

3. ábra. A BME280 és TSL2591 szenzorok

A második szakaszban a Solar Decathlon Europe 2019 versenyre készültünk, így fel kellett készítenünk a korábban felsorolt specifikációkra, mint vezeték nélküli kommunikáció és táplálás, valamint egy olyan hálózatot kellett terveznünk, amely alkalmas több csomópont kezelésére egyszerre. Ehhez először le kellett cserélni a mikrovezérlőt egy olyanra, amely rendelkezik beépített vezetéknélküli kommunikációval, a választás az ESP32-es mikrovezérlő sorozatra esett, mely kis mérete és fogyasztása miatt alkalmas a feladatra és a korábban megírt programok is kompatibilisek vele.

Továbbá fontos volt mindezt egy szenzor csomagban elhelyezni, ezért tervezni kellett egy szenzor dobozt. A szenzor dobozt 3D-s nyomtatással szerettük volna kivitelezni, ezért terveztem hozzá egy kompakt modellt (4. ábra, bal oldal). A végeredménnyel nem voltunk elégedettek, ezért ezt félre téve a tesztekhez egy egyszerübb modell mellett maradtunk, amely kapott egy kijelzőt is (4. ábra, jobb oldal).

Az eszköz továbbá bővült egy MICS-VZ-89 szenzorral is, amely az illékony szerves vegyületeket (VOC) koncentrációját vizsgálja a levegőben, lényegében a szagok és büzök mérésére szolgál. Ezt azért fontos mérni, mert a szagok nagyban befolyásolják a komfortérzetet, akár a kellemes illatok is lehetnek egy bizonyos koncentráció és idő után kellemetlenek. Általában ezektől könnyen megszabadulhatunk szellőztetéssel, de segítségével fény derülhet olyan problémákra is, amelyeket a ház karban tartásával lehet orvosolni, mint például a penész. 

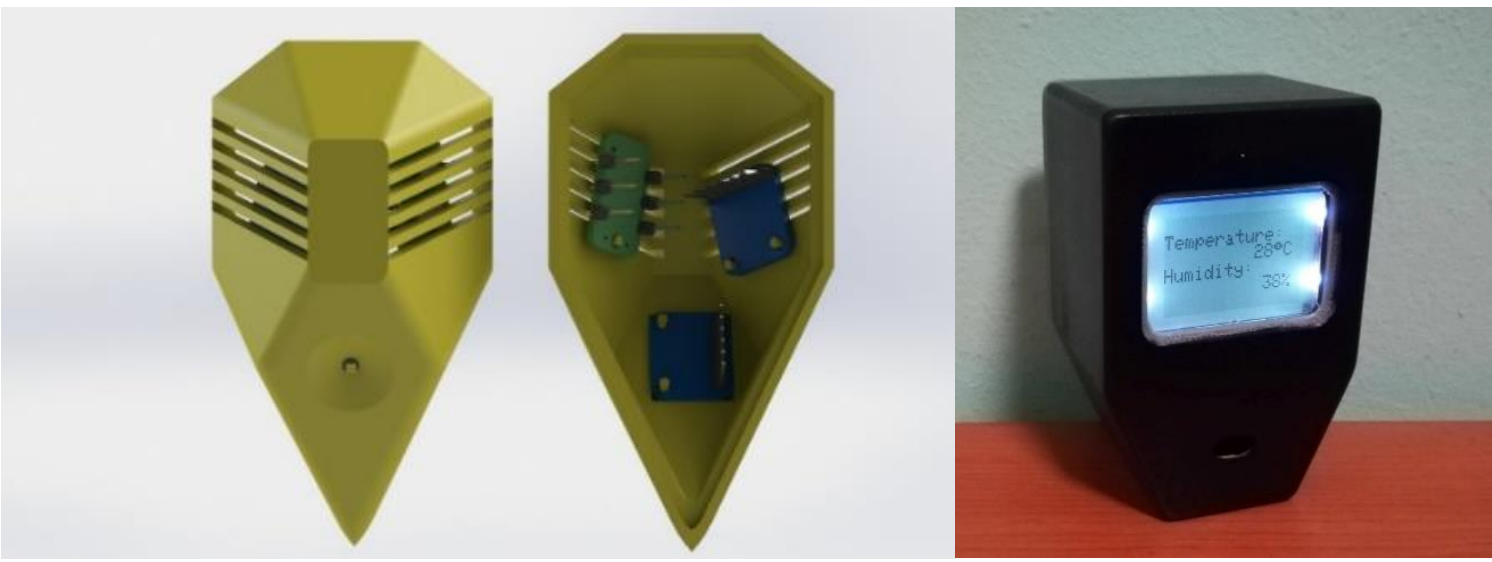

4. ábra. Szenzor doboz prototípusok

Az eszköz utolsó, jelenlegi állapota a Solar Decathlon Europe 2019 versenyen üzemelt. A rendszer egy nyomtatott áramkörön helyezkedik el és egy fából készült borítást kapott (5. ábra). A csomagban továbbá le lett cserélve a MICS szenzor egy SCD30-as szén-dioxid szenzorra, mivel az egészség szempontjából fontosabb paraméternek számít.

Képes vezetékes és vezetéknélküli kommunikációra, valamint az akkumulátoros külső megtáplálású üzemre, ez számos lehetőséget hordoz magában, mivel egy mobilis eszközt kapunk, így olyan helyekre is tehetjük, ahol nem tudjuk, vagy esztétika miatt nem akarjuk bedugni, valamint a legtöbb esetben nem áll rendelkezésre kiépített kommunikációs hálózat, így vezeték nélkül kell kommunikálnia.

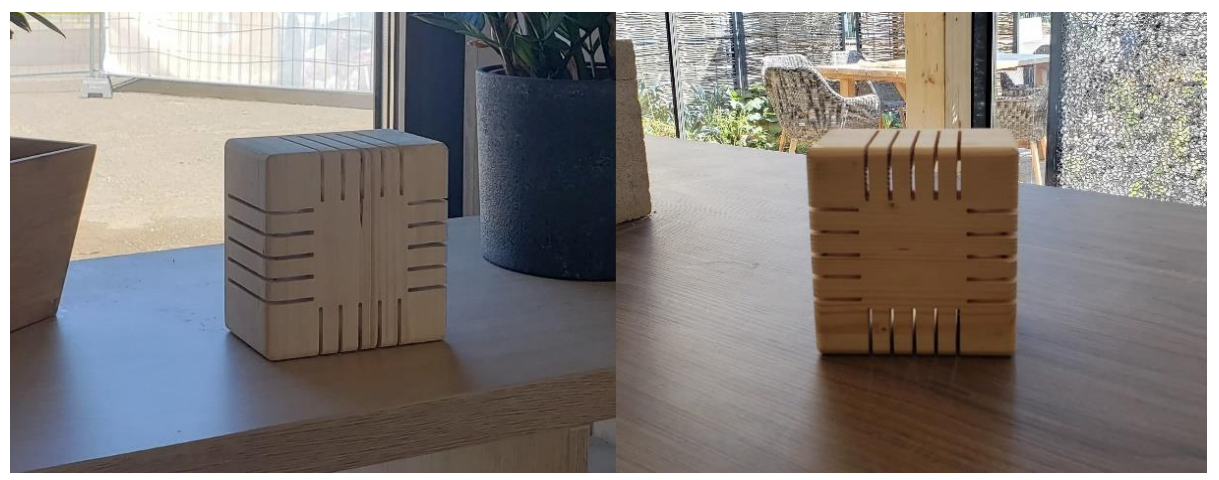

5. ábra. Az elkészült mérö eszköz

A legfontosabb újítás ebben a verzióban a tanácsadó interfész, amely kezdetleges módon, de müködik a házban. Segítségével költséghatékony módon oldhatjuk meg a komfort szabályozását. A teszt során konkrét értékek voltak meghatározva, amelyeket mi adtunk meg, ez volt a komfort intervalluma, ha ezeken a határokon kívül esik valamelyik paraméter a tanácsadó rendszer jelez, hogy miként befolyásolhatjuk ezt.

\section{5. Összefoglalás}

A kutatómunka célja az volt, hogy felderítsük azokat a komfortérzettel kapcsolatos tulajdonságokat, amelyek befolyásolják a lakó kényelmét az otthonában, valamint olyan eszközöket gyüjteni, amelyek 
az átlag felhasználó számára is elérhetővé teheti a tanácsadó rendszert. Jelenleg is müködik az eszköz, de még nem a végső formájában, további fejlesztési feladatok állnak még előtte. A következő időszakban tovább fogjuk fejleszteni a tanácsadó interfészt, a szenzorcsomagok energiahatékonyságát, valamint át kell dolgozni a tápellátást. Végeredményként szeretnénk egy olyan eszközt elkészíteni, ami kimutathatóan csökkenti az otthonok energiafogyasztását, mindamellett a komfortérzetet is optimális szinten tartja, alkalmazkodva a felhasználók elvárásaihoz. Ennek eléréséig, még sok munka és teszt áll a rendszer előtt.

\section{Köszönetnyilvánítás}

A cikkben ismertetett kutató munka az EFOP-3.6.1-16-2016-00011 jelü „Fiatalodó és Megújuló Egyetem - Innovatív Tudásváros - a Miskolci Egyetem intelligens szakosodást szolgáló intézményi fejlesztése" projekt részeként - a Széchenyi 2020 keretében - az Európai Unió támogatásával, az Európai Szociális Alap társfinanszírozásával valósul meg

\section{Irodalom}

[1] TNM rendelet az épületek energetikai jellemzőinek meghatározásáról 7/2006. (V. 24.)

[2] Bosch Sensortech: BME280 Technical data, https://www.boschsensortec.com/bst/products/all_products/bme280

[3] TSL2591 Datasheet, http://pdf1.alldatasheet.com/datasheetpdf/view/560759/AMSCO/TSL2591.html

[4] Pintér, J. M., Kiss, M. L.: Determination and measurement of parameters affecting indoor comfort In: Nawrocka, A.; Kot, A. (szerk.) 20th International Carpathian Control Conference, ICCC 2019 New York (NY), Amerikai Egyesült Államok: IEEE, (2019) pp. 1-6. Paper: 8766035, 6 p. https://doi.org/10.1109/CarpathianCC.2019.8766035

[5] Varga, Á.: Épületek energiafogyasztásának mérési lehetöségei ENELKO 2018 XIX. Nemzetközi Energetika-Elektrotechnika Konferencia SzámOkt 2018 XXVIII. Nemzetközi Számítástechnika és Oktatás Konferencia Tusnádfürdő, Románia: Erdélyi Magyar Müszaki Tudományos Társaság (EMT), (2018) pp. 345-349

[6] Pintér, J. M.: Nemzetközi hallgatói együttmüködés a Solar Decathlon Europe 2019 verseny keretén belül, ENELKO 2019 SzámOkt 2019: XX. Nemzetközi Energetika-Elektrotechnika Konferencia, XXIX. Nemzetközi Számítástechnika és Oktatás Konferencia Kolozsvár, Románia: Erdélyi Magyar Müszaki Tudományos Társaság (EMT), (2019) pp. 221-226. 